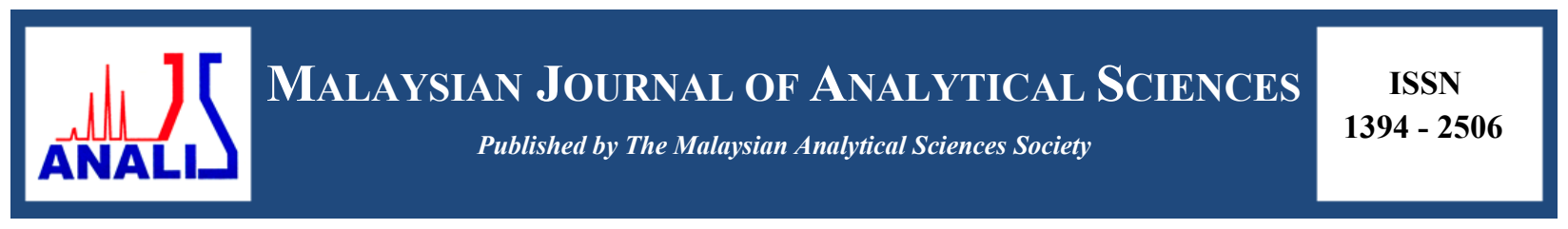

\title{
THE DETECTION OF FATTY ACID METHYL ESTER IN STERCULIACEAE
}

\author{
(Pengesanan Asid Lemak Metil Ester dalam Sterculiaceae) \\ Fathin Nurizati Samsul, Ibtisam Abdul Wahab*, Hannis Fadzillah Mohsin \\ Department of Pharmacology \& Chemistry, Faculty of Pharmacy, \\ Universiti Teknologi MARA, 42300 Puncak Alam, Selangor, Malaysia \\ *Corresponding author: ibtisam@puncakalam.uitm.edu.my
}

Received: 15 February 2017; Accepted: 2 January 2018

\begin{abstract}
This study introduces the Sterculiaceae plant family which are also called as malva nuts. They are utilised as the remedy against pharyngitis, tussis and constipation. Malva nut is a well-known plant, used in Thai traditional medicine as a cooling agent to treat fever, coughing and sore throats. The literatures mentioned that the Sterculiaceae extracts could function as antioxidative, antiulcer and would help in reducing body weight. The objective of this study is to investigate the constituents in the seeds extracts by using chromatography and Nuclear Magnetic Resonance (NMR) spectroscopy. The NMR spectrum revealed that the isolated compound from the chloroform extract was a mixture of an aromatic aldehyde and a fatty acid methyl ester (FAME) component. Future work is encouraged to reinvestigate the extract and establish more extensive NMR data. It is hoped that this study could increase the knowledge about the phytochemistry of Sterculiaceae family which then could be added as the line of today's drug.
\end{abstract}

Keywords: chromatography, fatty acid, spectroscopy, Sterculiaceae

\begin{abstract}
Abstrak
Kajian ini mempersembahkan keluarga tumbuhan Sterkuliaceae yang turut dikenali sebagai kacang malva. Ia digunakan sebagai rawatan faringitis, tussis dan konstipasi. Kacang malva merupakan pokok yang dikenali, digunakan dalam perubatan tradisional Thai sebagai agen penyejuk untuk menyembuh dari demam, batuk dan sakit tekak. Literatur menerangkan bahawa ekstrak Sterkuliaceae boleh berfungsi sebagai anti oksidatif, anti ulser dan mampu membantu pengurangan berat badan. Objektif kajian ini adalah untuk menyiasat kandungan ekstrak biji melalui kromatografi dan spektroskopi resonan magnetik nukleus (RMN). Spektrum RMN menunjukkan sebatian yang terasing dari ekstrak klorofom merupakan satu campuran aldehid aromatik dan komponen asid lemak metil ester. Lebih usaha digalakkan untuk mengkaji semula ekstrak dan mendapatkan lebih data RMN secara ekstensif. Adalah diharapkan agar penyelidikan ini mampu meningkatkan pengetahuan mengenai fitokimia keluarga Sterkuliaceae yang boleh dijadikan bahan perubatan masa kini.
\end{abstract}

Kata kunci: kromatografi, asid lemak, spektroskopi, Sterkuliaceae

\section{Introduction}

This study is parallel to a report that was launched by local researchers on the medicinal, phytochemistry and pharmacology of the Sterculiaceae [1]. These plants are called as malva nuts that can provide health benefits to human kinds. In Peninsular Malaysia, they are also known as "kembang semangkuk jantung" [1]. The uses of this species include as the remedy against pharyngitis, tussis and constipation. Malva nuts are well known plants, used in Thai traditional medicine as a cooling agent to treat fever, coughing and sore throats [2]. From the review, the 
medicinal property of Sterculiaceae was reported as antioxidative [3] and antiulcer [4]. The secondary metabolites that were previously isolated include the alkaloids [5] (Figure 1).<smiles>CCCCCCOC(=O)C[C@H](NC(=O)c1cc(=O)[nH]c2ccccc12)C(=O)O</smiles>

Sterculinine I<smiles>COC(=O)C[C@H](NC(=O)c1cc(=O)[nH]c2ccccc12)C(=O)O</smiles>

Sterculinine II

Figure 1. The chemical structures of Sterculinine I and Sterculinine II, which are the alkaloids, previously isolated from ethanol extract of the seed of Sterculia lychnophora

The objective of this study is to investigate the constituents in the Sterculiaceae seeds. The organic extraction was conducted to examine the natural compounds. The extracts are examined by using Thin Layer Chromatography (TLC). Nuclear Magnetic Resonance (NMR) spectroscopy are performed to examine the natural compounds.

\section{Materials and Methods}

The dried malva nuts were purchased from retails. The solvents such as hexane, chloroform $\left(\mathrm{CHCl}_{3}\right)$, ethyl acetate (EtOAc), ethanol (EtOH) and methanol (MeOH) (analytical reagent grade) were purchased from Merck (Germany). The plant material was grinded by using Waring commercial blender, single-speed, with a stainless steel jar. Then, the sample was extracted via maceration, in room temperature. The solvent was evaporated under reduced pressure, to obtain the dried crude extracts. The screening of natural compounds in the extract was perfomed by using TLC. The extract was separated by using commercially produced analytical silica gel chromatographic plates (Merck, $60 \mathrm{G} \mathrm{F}_{254}, 0.25 \mathrm{~mm}$ ). The plates were later developed in a TLC glass chamber by using mixtures of hexane:ethyl acetate $(2: 1 \mathrm{v} / \mathrm{v})$ as the mobile phase.The spots were visualized under both short and long wavelength ultraviolet (UV) light, $\lambda=254 \mathrm{~nm}$ and $366 \mathrm{~nm}$, respectively. Bosch heat gun was used to heat the plate $\left(250 \pm 2{ }^{\circ} \mathrm{C}\right)$ after spraying with the staining reagent (e.g. sulphuric anisaldehyde). Preparative silica gel chromatographic plates were utilized in order to fractionate and isolate the constituents. The NMR spectrum was obtained from the Bruker spectrometer $\left(500 \mathrm{MHz}, \mathrm{CDCl}_{3}\right)$.

\section{Results and Discussion}

The dried malva nuts were conveniently obtained from retails. It was noted that some product distributors labelled the seed part as the flower bowl. Figure 2(a). Figure (2b) displayed the TLC profiles of the organic crude extracts, showing separated and coloured spots.

From the preparative TLC (Figure 3), it was found that this technique was able to isolate the compounds from the chloroform extract, using a developing solvent system, which was hexane: ethyl acetate (7:1). The bands showed in Figure 3 were visualized under ultraviolet light $(\lambda=254$ and $360 \mathrm{~nm})$. Figure 3(a) shows that under UV light ( $\lambda=254$ $\mathrm{nm})$, two bands were observed. A blue band also can be seen $(\lambda=360 \mathrm{~nm}$, Figure 3(b)). Both left and right sides of the plate were sprayed with anisaldehyde (Figure 3(c)). There were two bands at the bottom of the plate in Figure $3(\mathrm{c})$. However the distance between them were quite close, it was recorded after the plate edges were coloured with anisaldehyde. All four bands or compounds were scrapped. They were subjected to NMR experiments (500 MHz, $\mathrm{CDCl}_{3}$ ) for structural elucidation. 


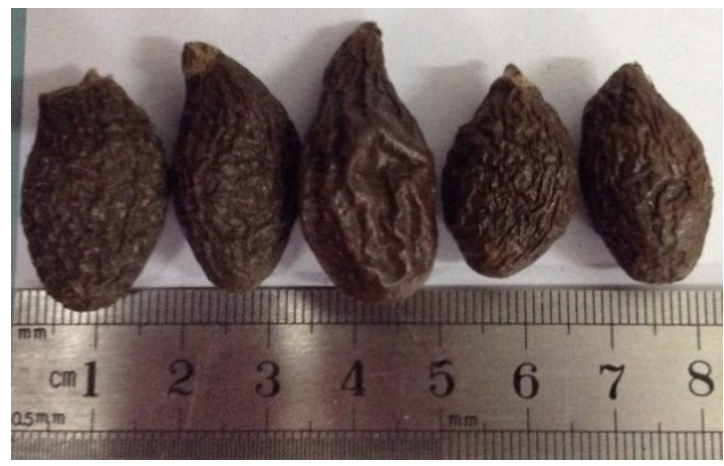

(a)

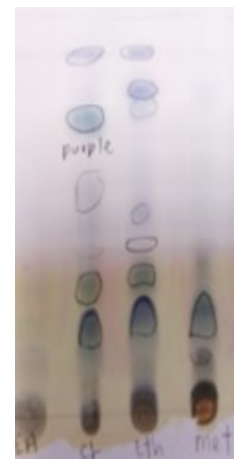

(b)

Figure 2. (a) The dry seeds of malva nut fruit, and (b) the TLC profiles of EtOAc, $\mathrm{CHCl}_{3}, \mathrm{EtOH}$ and $\mathrm{MeOH}$ crude extracts, developed with hexane:ethyl acetate $(7: 1 \mathrm{v} / \mathrm{v})$ as the mobile phase

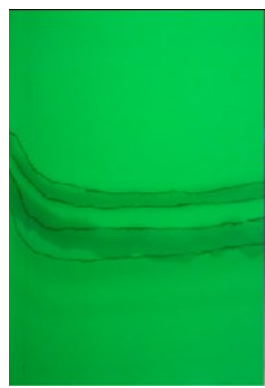

(a)

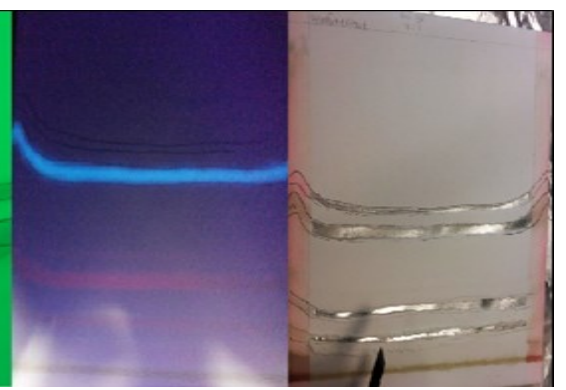

(b) (c)

Figure 3. The preparative plate:- $(a, b)$ observed under UV light and (c) after spraying with anisaldehyde.

Unfortunately, only Compound A (band 2 from the top of the plate, isolated from the chloroform extract, $\mathrm{Rf}=0.4$ ) shows significant ${ }^{1} \mathrm{H}-\mathrm{NMR}$ signals compared, with the other bands. From the ${ }^{1} \mathrm{H}-\mathrm{NMR}$ analysis, an aldehyde moiety (Figure 4(a)) was detected from the spectrum in Figure 4(b), at $\delta_{\mathrm{H}} 9.91 \mathrm{ppm}$. This finding would be in in line with an evidence [6] that identified an aldehyde named 3-(3,4-dimethoxyphenyl) 2-propenal. The aldehyde was recorded from Helicteres angustifolia (L.), which also belongs to the Sterculiaceae family. It was noted that the olefinic-type of protons $\left(\delta_{\mathrm{H}} 6-7 \mathrm{ppm}\right)$ were absent. Nevertheless, the rest of the peaks still require further investigation. This is due to the occurrence of centrosymmetrical multiplets at the chemical shifts of $\delta_{\mathrm{H}} 4.16$ and $4.30 \mathrm{ppm}$ (doublet of doublets, $\mathrm{J}=12,4 \mathrm{~Hz}, 2 \mathrm{H}$ ).

It is believed that a mixture of both aromatic aldehyde $\left(\delta_{\mathrm{H}} 7-10 \mathrm{ppm}\right)$ and fatty acid $\left(\delta_{\mathrm{H}} 0-5.5 \mathrm{ppm}\right)$ compounds could present in current study (Figure 3b). Hence, a cross-referencing of other Sterculia's composition is performed. It was mentioned that oils from Sterculia seeds, collected from the tropical rain forests of south eastern Mexico, are commonly used for human and animal nutrition. These oils contain cyclopropene fatty acids, whose consumption is related with beneficial, as well as detrimental physiological effects [7]. In a following report, Sterculia species might contain fatty acids with branched ester derivatives [7] (Figure 5). It is also confirmed that the uniqueness of Sterculia's fatty acid, sets in the presence of a cyclopropene unit. It may contribute to up to $70 \%$, in the form of sterculic acid [(9,10-methylene-9-octadecenoic acid, Figure 5(a) and malvalic acid (8,9-methylene-8-heptadecenoic acid, Figure (5b). 


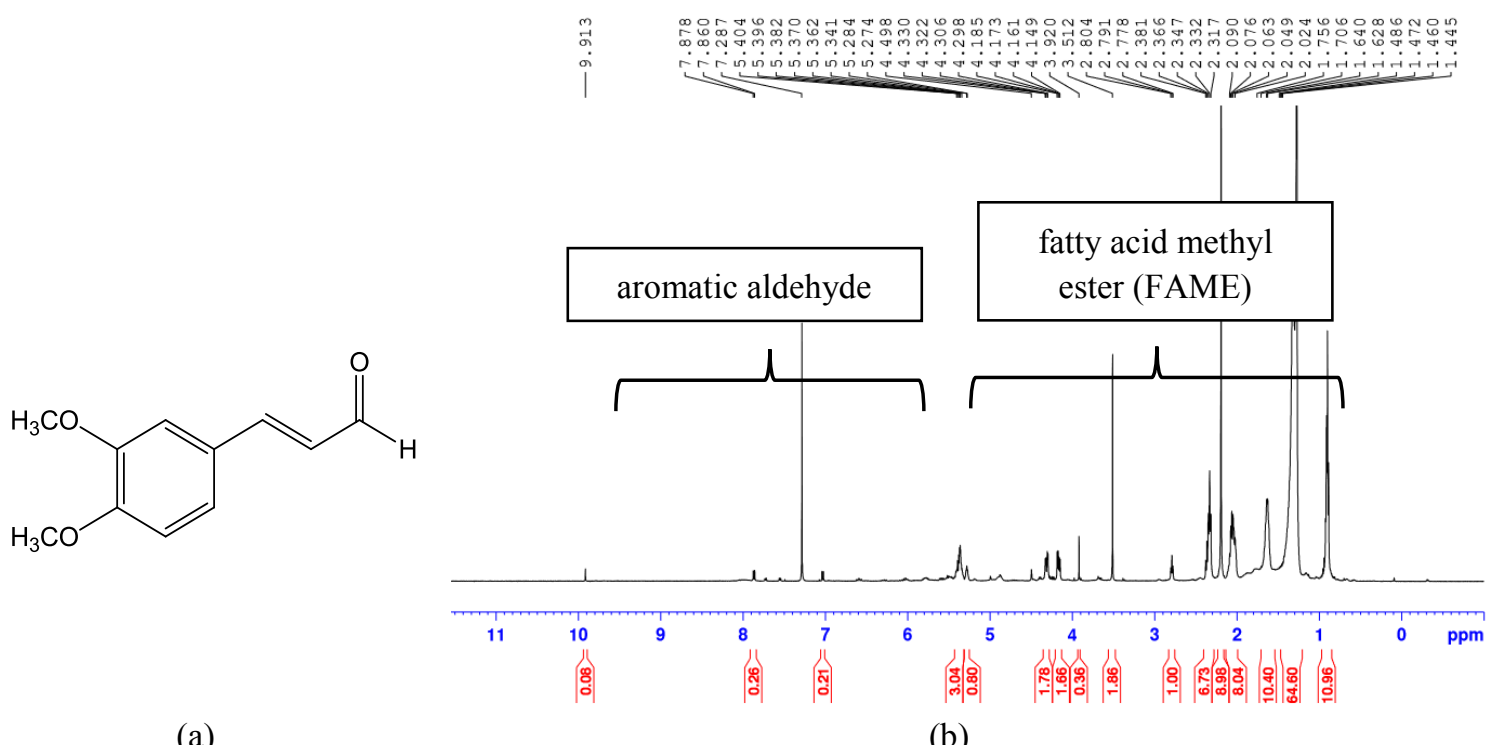

(a)

(b)

Figure 4. (a) 3-(3,4-dimethoxyphenyl)2-propenal was identified from Helicteres angustifolia (L.) (Sterculiaceae) and (b) the ${ }^{1} \mathrm{H}-\mathrm{NMR}$ spectrum $\left(500 \mathrm{MHz}, \mathrm{CDCl}_{3}\right.$ ) of the chemical composition of the malva nut

The total ion current gas chromatograms of Sterculia hexanoic seed extracts were established, in order to determine the fatty acids profile [7]. This is followed by the determination of mass spectra of sterculic acid (Figure 5a). It was demonstrated that cyclopropene fatty acids (CPFA) are unusual fatty acids, which contain a three member carbocyclic ring, forming the center of their 18 and 17 carbon chains.

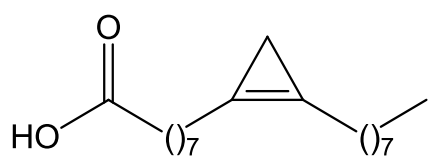

(a)

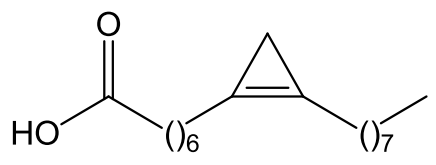

(b)

Figure 5. The chemical structure of (a) sterculic acid (9,10-methylene-9-octadecenoic acid) and (b) malvalic acid (8,9-methylene-8-heptadecenoic acid)

In this current study, the assignment of the protons in the fatty acid methyl ester (FAME) is possible, as shown in Table 1 and Figure 6 [8].

Table 1. The comparison of ${ }^{1} \mathrm{H}-\mathrm{NMR}\left(500 \mathrm{MHz}, \mathrm{CDCl}_{3}\right)$ data of compound A with ${ }^{1} \mathrm{H}-\mathrm{NMR}\left(400 \mathrm{MHz}, \mathrm{CDCl}_{3}\right)$ data of FAME from the literature [8]

\begin{tabular}{|c|c|c|}
\hline \multicolumn{2}{|c|}{${ }^{1} \mathrm{H}-\mathrm{NMR}$ chemical shift, $\delta_{\mathrm{H}}$ in ppm (multiplicity) } & \multirow[b]{2}{*}{ Types of protons } \\
\hline $\begin{array}{l}\text { Compound A } \\
\left(500 \mathrm{MHz}, \mathrm{CDCl}_{3}\right)\end{array}$ & $\begin{array}{l}\text { FAME from } S \text {. foetida L. Oil [8] } \\
\left(400 \mathrm{MHz}, \mathrm{CDCl}_{3}\right)\end{array}$ & \\
\hline $0.87(\mathrm{t}, \mathrm{J}=6.5 \mathrm{~Hz})$ & $0.85(\mathrm{t}, \mathrm{J}=6.8 \mathrm{~Hz})$ & $\mathrm{CH}_{3} \mathrm{CH}_{2-}$ \\
\hline $0.91(\mathrm{~s})$ & $0.73(\mathrm{~s})$ & $-\mathrm{C}-\mathrm{C} \mathbf{H}_{2}-\mathrm{C}$-,cylopropene $(2 \mathrm{H})$ \\
\hline $1.32-1.48(\mathrm{~m})$ & $1.17-1.40(\mathrm{~m})$ & $-\mathrm{CH}_{2-}^{-}$ \\
\hline
\end{tabular}


Table 1 (cont'd). The comparison of ${ }^{1} \mathrm{H}-\mathrm{NMR}\left(500 \mathrm{MHz}, \mathrm{CDCl}_{3}\right)$ data of compound A with ${ }^{1} \mathrm{H}-\mathrm{NMR}(400 \mathrm{MHz}$, $\mathrm{CDCl}_{3}$ ) data of FAME from the literature [8]

\begin{tabular}{|c|c|c|}
\hline \multicolumn{2}{|c|}{${ }^{1} \mathrm{H}-\mathrm{NMR}$ chemical shift, $\delta_{\mathrm{H}}$ in ppm (multiplicity) } & \multirow[b]{2}{*}{ Types of protons } \\
\hline $\begin{array}{l}\text { Compound A } \\
\left(500 \mathrm{MHz}, \mathrm{CDCl}_{3}\right)\end{array}$ & $\begin{array}{l}\text { FAME from } S \text {. foetida } \mathrm{L} \text {. Oil [8] } \\
\left(400 \mathrm{MHz}, \mathrm{CDCl}_{3}\right)\end{array}$ & \\
\hline $0.87(\mathrm{t}, \mathrm{J}=6.5 \mathrm{~Hz})$ & $0.85(\mathrm{t}, \mathrm{J}=6.8 \mathrm{~Hz})$ & $\mathrm{CH}_{3} \mathrm{CH}_{2-}$ \\
\hline $0.91(\mathrm{~s})$ & $0.73(\mathrm{~s})$ & -C-CH${ }_{2}$-C-,cylopropene (2H) \\
\hline $1.32-1.48(\mathrm{~m})$ & $1.17-1.40(\mathrm{~m})$ & $-\mathrm{CH}_{2-}^{-}$ \\
\hline $1.64(\mathrm{~m})$ & $1.59(\mathrm{~m})$ & $-\mathrm{CH}_{2-}^{-}$ \\
\hline $2.06(\mathrm{~m})$ & $2.27(\mathrm{~m})$ & Allylic $-\mathrm{CH}_{2}$ - of cyclopropene $(2 \mathrm{H})$ \\
\hline $2.33(\mathrm{t}, \mathrm{J}=7.5 \mathrm{~Hz})$ & $2.00(\mathrm{~m}, \mathrm{~J}=7.0 \mathrm{~Hz})$ & $\mathrm{CH}_{2} \mathrm{COO}-(4 \mathrm{H})$ \\
\hline $2.36(\mathrm{~m})$ & $2.27(\mathrm{t}, \mathrm{J}=7.0 \mathrm{~Hz})$ & Allylic $-\mathrm{CH}_{2}$ - of cyclopropene $(2 \mathrm{H})$ \\
\hline $2.79(\mathrm{t}, \mathrm{J}=6.5 \mathrm{~Hz})$ & $2.74(\mathrm{t}, \mathrm{J}=6.0 \mathrm{~Hz})$ & $=\mathrm{CH}-\mathrm{C} \mathbf{H}_{2}-\mathrm{CH}=(2 \mathrm{H})$ \\
\hline $3.51(\mathrm{~s})$ & $3.63(\mathrm{~m})$ & $-\mathrm{OCH}_{3}$ \\
\hline $4.16(\mathrm{dd}, \mathrm{J}=12,4 \mathrm{~Hz})$ & 4. $14(\mathrm{dd}, \mathrm{J}=11.9,6.0 \mathrm{~Hz})$ & $-\mathrm{OCH}\left(\mathrm{CH}_{2}\right)_{2}(2 \mathrm{H})$ \\
\hline $4.30(\mathrm{dd}, \mathrm{J}=12,4 \mathrm{~Hz})$ & $4.29(\mathrm{dd}, \mathrm{J}=11.9,4.3 \mathrm{~Hz})$ & $-\mathrm{OCH}\left(\mathrm{CH}_{2}\right)_{2}(2 \mathrm{H})$ \\
\hline $5.28(\mathrm{~m})$ & $5.26(\mathrm{~m})$ & $-\mathrm{OCH}\left(\mathrm{CH}_{2}\right)_{2}(1 \mathrm{H})$ \\
\hline $5.39(\mathrm{~m})$ & $5.30(\mathrm{~m})$ & $-\mathrm{CH}=\mathrm{CH}-(4 \mathrm{H})$ \\
\hline
\end{tabular}

$\mathrm{dd}=$ double of doublet, $\mathrm{m}=$ multiplet, $\mathrm{s}=$ singlet, $\mathrm{t}=$ triplet

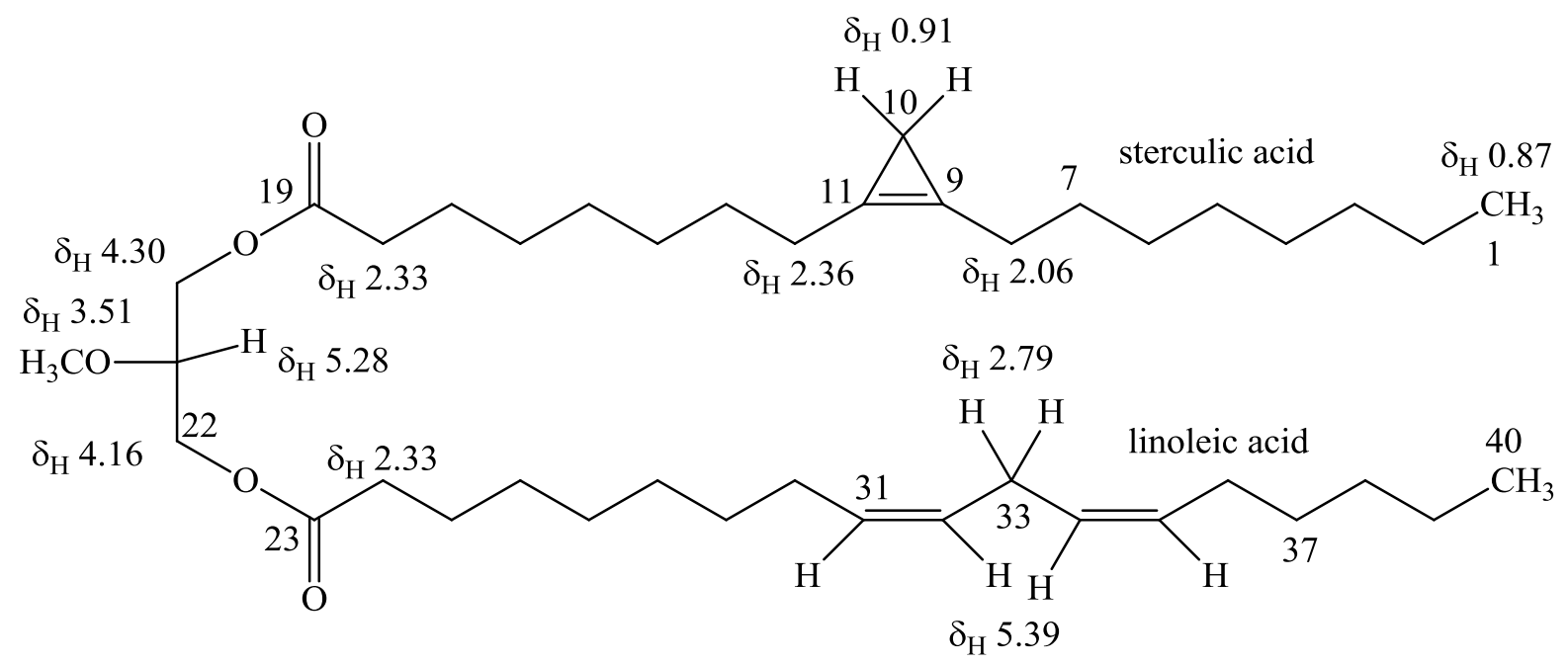

Figure 6. The structure of fatty acid methyl ester (FAME), from the malva nut showing the major ${ }^{1} \mathrm{H}-\mathrm{NMR}$ chemical shift (ppm). The carbons are numbered accordingly 
According to Table 1 and Figure 6, ${ }^{1} \mathrm{H}-\mathrm{NMR} \delta(\mathrm{ppm})$ values, in $\mathrm{CDCl}_{3}$ are $5.39(4 \mathrm{H}, m,-\mathrm{CH}=\mathrm{CH}-), 5.28(1 \mathrm{H}, m,-$ $\left.\mathrm{OCH}\left(\mathrm{CH}_{2}\right)_{2}\right), 4.30\left(2 \mathrm{H}, d d, \mathrm{~J}=12,4 \mathrm{~Hz},-\mathrm{OCH}\left(\mathrm{CH}_{2}\right)_{2}\right), 4.16\left(2 \mathrm{H}, \mathrm{dd}, \mathrm{J}=12,4 \mathrm{~Hz},-\mathrm{OCH}\left(\mathrm{CH}_{2}\right)_{2}, 3.51\left(\mathrm{~s},-\mathrm{OCH}_{3}\right), 2.79\right.$ $\left(2 \mathrm{H}, \mathrm{t}, \mathrm{J}=6.5,=\mathrm{CH}-\mathrm{CH}_{2}-\mathrm{CH}=\right), 2.36\left(2 \mathrm{H}, \mathrm{m}\right.$, Allylic $-\mathrm{CH}_{2}$ - of cyclopropene), $2.33\left(4 \mathrm{H}, \mathrm{t}, \mathrm{J}=7.5 \mathrm{~Hz}, \mathrm{CH}_{2} \mathrm{COO}-\right)$, $2.06\left(2 \mathrm{H}, \mathrm{m}\right.$, Allylic $-\mathrm{CH}_{2}-$ of cyclopropene $), 1.64\left(\mathrm{~m},-\mathrm{CH}_{2}-\right), 1.32-1.48(\mathrm{~m},-\mathrm{CH} 2-), 0.91\left(2 \mathrm{H}, \mathrm{s},-\mathrm{C}-\mathrm{CH}_{2}-\mathrm{C}-\right.$ ,cylopropene), 0.87 (t, $\mathrm{J}=6.5 \mathrm{~Hz}, \mathrm{CH}_{3} \mathrm{CH}_{2}-$ ).

Both Figure 4 and 6, plus the chemical shifts in Table 1, presented the protons of Sterculia's fatty acid methyl ester (FAME) that could were characterized by using ${ }^{1} \mathrm{H}-\mathrm{NMR}$ spectroscopy. ${ }^{1} \mathrm{H}$ NMR spectrum of compound A showed a diagnostic peak as fatty acid with branched ester derivatives appearing as singlet at $\delta_{\mathrm{H}} 0.91\left(\mathrm{C}^{-} \mathrm{CH}_{2}-\mathrm{C}\right)$, indicating two hydrogen of the cyclopropene ring at $\mathrm{C} 10$. The carbon at $\mathrm{C} 8 / \mathrm{C} 12$ appeared as multiplet signals at $\delta_{\mathrm{H}} 2.36$ and $2.06 \mathrm{ppm}$ respectively, indicate the allylic $-\mathrm{CH}_{2}$ - of cyclopropene while a triplet at $\delta_{\mathrm{H}} 0.87 \mathrm{ppm}$ due to terminal methyl hydrogen groups of all fatty acids or the methyl esters which compose the triacylglycerol (C1). The occurrences of double of doublet at the chemical shifts of $\delta_{\mathrm{H}} 4.16$ and $4.30 \mathrm{ppm}$, in addition to the multiplet at $\delta_{\mathrm{H}}$ $5.28 \mathrm{ppm}$ were contributed by the $-\mathrm{CH}_{2}$ and $-\mathrm{CH}$ resonances from the glycerol backbone. The presence of proton at $\mathrm{C} 34$, the conjugated double bonds of linoleic acid, was assigned as the multiplet at $\delta_{\mathrm{H}} 5.39 \mathrm{ppm}$. Since the hydrogen atoms of the linoleic acid are on the same side the molecule, the likely arrangement of the linoleic acid is the cisisomer. It could be deduced that, both sterculic and linoleic acids could construct the chemical structure. Therefore, compound A in this Sterculia sample is suggested as a FAME molecule, (9Z,12Z)-,methoxy-3-((8-(2,octylcyclo prop-1-en-1-yl)octanoyl)oxy)propyloctadeca-9,12-dieoate (Figure 6) with proposed molecular formula of $\mathrm{C}_{41} \mathrm{H}_{72} \mathrm{O}_{5}$, $(\mathrm{MW}=645.01 \mathrm{~g} / \mathrm{mol})$. These results agreed with the assignment with the chemical shifts of the FAME from Sterculia foetida L. oil, reported by Manurung et al. shown in Table 1 [8].

\section{Conclusion}

This research could increase the knowledge on the pharmacochemistry of the Sterculiaceae. The ${ }^{1} \mathrm{H}-\mathrm{NMR}$ spectroscopic analysis suggested that compound A from the chloroform extract, was a mixture of an aromatic aldehyde and a fatty acid methyl ester (FAME). The FAME in this Sterculia sample consists of sterculic and linoleic acids. Sterculic acid is composed of around 55\%, which is the highest content, as reported in Sterculia foetida seeds oil [7]. Though compound A might not be a secondary metabolite, its primary activity correlates with its benefits in reducing the body weight and improving the hepatic inflammation [9]. Further study is needed to re-investigate a higher purity of FAME. It is hoped to provide evidence in order to support the traditional uses of malva nut in folklore medicine.

\section{Acknowledgement}

The authors wish to thank Faculty of Pharmacy, UiTM for the support. The authors would also like to acknowledge Mr. Mohd Syukri Baharudin, Assistant Science Officer, Atta-ur-Rahman Institute for Natural Products Discovery (AuRIns), UiTM, Puncak Alam Campus, Selangor Darul Ehsan.

\section{References}

1. Al Muqarrabun, L. M. R. and Ahmat, N. (2015). Medicinal uses, phytochemistry and pharmacology of family Sterculiaceae: A review. European Journal of Medicinal Chemistry, 92: 514-530.

2. Palve, A., Shetty, P., Pimpliskar, M. and Jadhav, R. N. (2015). HPTL method for qualitative determination of phytochemical compunds in extract of Sterculia lychnophora. International Journal Research Ayurveda Pharmaceutical, 6: 358 - 365 .

3. Petchlert, C., Boonsala, P., Payon, V., Kitcharoen, K. and Promsopa, S. (2012). Proceeding of the $4^{\text {th }}$ International Conference on Natural Products for Health and Beauty, $28^{\text {th }}-30^{\text {th }}$ November 2012, Thailand.

4. Ogale, S. C., Kasture, S. B., Kasture, V. S., Tiwari, R. and Temrikar, Z. (2014). Screening of methanolic extract of sterculia scaphigera wall seeds for ulcerprotective \& antioxidant activity. World Journal of Pharmacy and Pharmaceutical Sciences, 4: 1332-1346.

5. Wang, R.-F., Yang, X.-W., Ma, C.-M., Shang, M.-Y., Liang, J.-Y., Wang, X., Cai, S. Q. and Shoyama, Y. (2003). Alkaloids from the seeds of Sterculia lychnophora (Pangdahai). Phytochemistry, 63: 475-478.

6. Chen, W., Tang, W., Lou, L. and Zhao, W. (2006). Phytochemistry, 67: 1041-1047. 
7. Herrera-Meza, S., Martínez, A. J., Sánchez-Otero, M. G., Mendoza-López, M. R., García-Barradas, O., OrtizViveros, G. R. and Oliart-Ros, R. M. (2014). Fatty acid composition and some physicochemical characteristics of Sterculia apetala seed oils. Grasas Y Aceites, 65: e039.

8. Manurung, R., Daniel, L., van de Bovenkamp, H. H., Buntara, T., Maemunah, S., Kraai, G., Makertihartha, I. G. B. N., Broekhuis, A. A. and Heeres, H. J. (2012). European Journal of Lipid Science and Technology, 114: 31-48.

9. Phlicharoenphon, W., Gritsanapan, W. and Sithisarn, P. (2013). Thai Journal of Pharmaceutical Sciences, 38: $58-60$. 